\title{
EVALUATION OF IN VITRO ANTIOXIDANT POTENTIAL OF AQUEOUS ROOT EXTRACT OF CLERODENDRUM SERRATUM L.
}

\author{
RAJ KUMAR TIWARI ${ }^{1 *}$, UDAYABANU M $^{2}$, SILPI CHANDA ${ }^{3}$
}

${ }^{1}$ Department of Pharmacognosy, Sunder Deep Pharmacy College, Dasna, Ghaziabad - 201 001, Uttar Pradesh, India. ${ }^{2}$ Department of Pharmacy, Jaypee University of Information Technology, Solan - 173 234, Himachal Pradesh, India. ${ }^{3}$ Department of Pharmacognosy, Pharmacy Institute, NIET, Greater Noida - 201 010, Uttar Pradesh, India. Email: raj_t365@yahoo.com

Received: 02 January 2017, Revised and Accepted: 27 January 2017

ABSTRACT

Objective: The intent of this report was to investigate the effect of aqueous root extract of Clerodendrum serratum L. for antioxidant activity using divergent models, namely, 2,2-diphenyl-1-picrylhydrazyl (DPPH) scavenging assay, superoxide scavenging assay, and ferric reducing antioxidant power (FRAP) assay.

Methods: The root of $C$. serratum was extracted using water. The yield of aqueous extract was $10 \%$ w/w. The outcome was examined statistically by the regression method.

Results: The inhibitory concentration $50 \%$ values are 85.43 and $107.59 \mu \mathrm{g} / \mathrm{ml}$ for DPPH radical scavenging assay and superoxide scavenging assay, respectively, whereas FRAP showed a significant reducing power activity with increased concentration of sample. The pilot study showed a significant correlation existed between concentrations of the extract and percentage engrossment of free radicals.

Conclusion: The antioxidant property may be corresponding to the polyphenols and flavonoids adjacent in the extract. These results clearly revealed that $C$. serratum might be effective against diseases analogous with free radical mediated.

Keywords: Clerodendrum serratum, 2,2-diphenyl-1-picrylhydrazyl, Superoxide, Ferric reducing antioxidant power, Rutin, Antioxidant.

(c) 2017 The Authors. Published by Innovare Academic Sciences Pvt Ltd. This is an open access article under the CC BY license (http://creativecommons. org/licenses/by/4. 0/) DOI: http://dx.doi.org/10.22159/ajpcr.2017.v10i4.16930

\section{INTRODUCTION}

Human and plant relation is as old as its start of civilization and human being extensively depends on plant for food and cure [1]. India is known for its rich biodiversity and the use of herbal drugs since ancient time is well known and practiced as mentioned in Ayurveda [2]. Natural products play a foundation for drug discovery either in natural form or as lead for synthetic drug development. Isolation, extraction and modification of biologically active compounds lead toward novel and synthetic drugs from natural products by suitable biological or chemical means and had been significantly contributed for potent drugs [3].

Free radicals and reactive oxygen species (ROS) are generated in living cells as a result of physiological and biochemical processes which are associated with many chronic diseases, such as cancer, diabetes, aging, and other degenerative diseases in humans usually due to oxidative damage of proteins, lipids, and DNA [4]. Phenolic classes of secondary metabolites have antioxidant properties and are acknowledged for various ailments. They possess antiapoptosis and anti-inflammatory activities, and these biological connections are due to the potentiality of phenols [5]. ROS levels can dramatically increase, resulting in significant damage to cell structure [6]. Lifestyle disorders such as heart problems [7], inflammation, stroke, and metabolic disorders are common problems in human community [8]. Studies reveal that there is a correlation between high intake/high blood levels of antioxidants and low incidence of different types of cancer [9]. Antioxidant compounds that hunt free radicals help safeguard against different kinds of degenerative diseases [10]. Plants, as the source of medicine, have been playing an important role to promote our health. The search for potent natural antioxidants which also have traditional claim with medicinal value is still in progressing. One such plant is Clerodendrum serratum L. belonging to family Verbenaceae, commonly known as Bharangi. C. serratum is a deciduous shrub widely distributed in Western Ghats [11]. In Ayurveda, the plant is popular as Bharangi (Sanskrit) and customarily known as Blue Glory (English). As per the traditional claims, the roots are the potential source of drug for ailments such as allergic disease, body soreness, respiratory illness, infectious disease, dropsy, eye diseases, fever, inflammations, malaria, ophthalmia, rheumatism, snakebite, tuberculosis, ulcers, and wounds [12]. The current study was focused on its antioxidant properties which may the main reason of its traditional claim.

\section{METHODS}

Collection and authentication of plant material

Roots of C. serratum L. were purchased from Faizabad (Uttar Pradesh) in January. The taxonomical identification was done from Department of Agronomy, Acharya Narendra Dev Agriculture Technical University, Dist. Faizabad, Uttar Pradesh.

\section{Preparation of extract}

The collected brown-colored roots (100 g) were extracted (decoction) with water $(500 \mathrm{ml})$ at a temperature not exceeding $110^{\circ} \mathrm{C}$ for $2 \mathrm{hrs}$. The extract was strained and lyophilized. The yield of obtained dried extract was $10 \% \mathrm{w} / \mathrm{w}$.

\section{Chemicals}

Chemicals were procured from Sigma-Aldrich Co., St. Louis, USA. All other chemicals/solvent adopted was of analytical grade.

\section{2,2-diphenyl-1-picrylhydrazyl (DPPH) radical scavenging assay}

The DPPH assay of extract was determined using ultraviolet spectrophotometer $[13,14]$, which involved the preparation of standard, test, and control. 


\section{Preparation of standard rutin solutions}

Different solutions $(20-100 \mu \mathrm{g} / \mathrm{ml})$ of the rutin were prepared in methanol. $1.5 \mathrm{ml}$ of each solution of rutin was mixed with $1.5 \mathrm{ml}$ of $200 \mu \mathrm{M}$ DPPH solution and fecundated for 30 minutes at room temperature in dark. Absorbance of each solution was taken after 30 minutes against methanol (as blank) at $517 \mathrm{~nm}$.

\section{Preparation of test solutions}

Different solutions of the extract were prepared in methanol to give concentrations in the range of $20-100 \mu \mathrm{g} / \mathrm{ml} .1 .5 \mathrm{ml}$ of each extract solution was blended with $200 \mu \mathrm{M}$ DPPH solution and incubated for 30 minutes at room temperature. Optical density was measured after 30 minutes against methanol (as blank) at $517 \mathrm{~nm}$.

\section{Preparation of control solution}

For control, $1.5 \mathrm{ml}$ of methanol was mixed with $200 \mu \mathrm{M}$ DPPH solution and incubated for 30 minutes at room temperature in dark. Absorbance of the control was taken after 30 minutes against methanol (as blank) at $517 \mathrm{~nm}$. Percentage antioxidant activity of plant extract and rutin was calculated using the following formula:

\%Inhibition $=\frac{\text { Control }- \text { Sample }}{\text { Control }} \times 100$

\section{Superoxide scavenging assay}

Reagents and chemicals

$1 \mathrm{ml}$ of alkaline dimethyl sulfoxide (DMSO) contains $0.1 \mathrm{ml}$ of $5 \mathrm{mM}$ $\mathrm{NaOH}$ and $0.9 \mathrm{ml}$ of DMSO. Nitroblue tetrazolium (NBT) solution was prepared by dissolving $25 \mathrm{mg}$ of NBT in $25 \mathrm{ml}$ DMSO to give concentration of $1 \mathrm{mg} / \mathrm{ml}$.

\section{Methodology}

Different concentrations $(20-100 \mu \mathrm{g} / \mathrm{ml})$ of rutin and test sample were prepared. To the reaction mixture carrying $0.1 \mathrm{ml}$ of NBT, $0.3 \mathrm{ml}$ of extract and $1 \mathrm{ml}$ of alkaline DMSO was added to give a final volume of $1.4 \mathrm{ml}$, and the absorbance was fixed at $560 \mathrm{~nm}$. Plain DMSO used as blank and reaction mixture without extract (water in place of extract) used as control. Depreciate absorbance of the reaction mixture designated the increasing of superoxide anion scavenging activity. $50 \%$ inhibition of extract was determined by plotting a graph between absorbance and concentration [15]

$\%$ Inhibition $=\frac{\text { Control }- \text { Sample }}{\text { Control }} \times 100$

\section{Ferric reducing antioxidant power (FRAP) assay}

The endowment to reduce ferric ions was deliberated using the method described by Benzie and Strain $[16,17]$

\section{Reagent preparation}

FRAP reagent was accomplished by mixing $300 \mathrm{mM}$ sodium acetate buffer ( $\mathrm{pH}$ 3.6), $10.0 \mathrm{mM}$ tripyridyl triazine solution, and $20.0 \mathrm{mM}$ $\mathrm{FeCl}_{3} \cdot 6 \mathrm{H}_{2} \mathrm{O}$ solution in a proportion of $10: 1: 1$ in volume.

\section{Procedure}

Rutin and test samples at divergent combinations $(100-500 \mu \mathrm{g} / \mathrm{ml})$ were added to $3 \mathrm{ml}$ of FRAP reagent, and the counterpoise was incubated at $37^{\circ} \mathrm{C}$ for 30 minutes. The increase in absorbance at $593 \mathrm{~nm}$ was measured. The antioxidant capacity is based on the ability to reduce ferric ions of sample to ferrous ions.

\section{RESULTS AND DISCUSSION}

The main mechanism behind the antioxidation properties of any compound is inhibition of generation of free radicals. This can be achieved either by scavenging or decomposition of lipid peroxides, breaking the autoxidative chain reaction or by reducing radicals. The antioxidant property of polyphenolic compound depends on the number and position of free $\mathrm{OH}$ groups present on the particular molecule. The antioxidant property of the extract was analyzed using DPPH, stable free radicals. Antioxidants are reacts with DPPH and reduce it to DPPH-H. Concentration ranges were used 20-100 $\mu \mathrm{g} / \mathrm{ml}$. At a concentration $100 \mu \mathrm{g} / \mathrm{ml}$, the inhibition of the extract reached to $56.53 \%$, whereas the standard rutin showed $68.57 \%$ of inhibition (Table 1). The inhibitory concentration $50 \%\left(\mathrm{IC}_{50}\right)$ value for the extract was found to be $85.43 \mu \mathrm{g} / \mathrm{ml}$. Figs. 1 and 2 showed the response curve of DPPH radical scavenging activity of rutin and aqueous extracts of the C. serratum, respectively.

Superoxide radicals were generated by the hypoxanthine-xanthine oxidase and the NBT system. The decrease in absorbance indicated the consumption of superoxide radicals. The superoxide scavenging activity of the extract and standard was shown in Table 2. The percentage of superoxide scavenging activity of the extract is $47.73 \%$ at a concentration $100 \mu \mathrm{g} / \mathrm{ml}$. The $\mathrm{IC}_{50}$ value was found to be $11.18 \mu \mathrm{g} / \mathrm{ml}$. Figs. 3 and 4 show the response curve of superoxide scavenging assay where \% superoxide scavenging inhibition is plotted against concentrations of aqueous root extract.

Fig. 5 shows the reducing power of the extract and the standard rutin, whereas Table 3 shows the FRAP in an increasing manner with increased concentration. The reducing power of the extract indicates that the extract must contain electron donors.

Table 1: DPPH radical scavenging assay

\begin{tabular}{|c|c|c|c|c|c|}
\hline \multirow[t]{2}{*}{ S.No } & \multirow{2}{*}{$\begin{array}{l}\text { Concentration } \\
(\mu \mathrm{g} / \mathrm{ml})\end{array}$} & \multicolumn{2}{|c|}{ Inhibition (\%) } & \multicolumn{2}{|c|}{$\mathrm{IC}_{50}(\mu \mathrm{g} / \mathrm{ml})$} \\
\hline & & Rutin & Sample & Rutin & Sample \\
\hline 1 & 20 & $52.86 \pm 0.089$ & $31.42 \pm 0.399$ & 10.10 & 85.43 \\
\hline 2 & 40 & $55.50 \pm 0.358$ & $36.42 \pm 0.224$ & & \\
\hline 3 & 60 & $58.30 \pm 0.016$ & $40.97 \pm 0.145$ & & \\
\hline 4 & 80 & $61.68 \pm 0.092$ & $45.81 \pm 0.083$ & & \\
\hline 5 & 100 & $68.57 \pm 0.342$ & $56.53 \pm 0.347$ & & \\
\hline
\end{tabular}

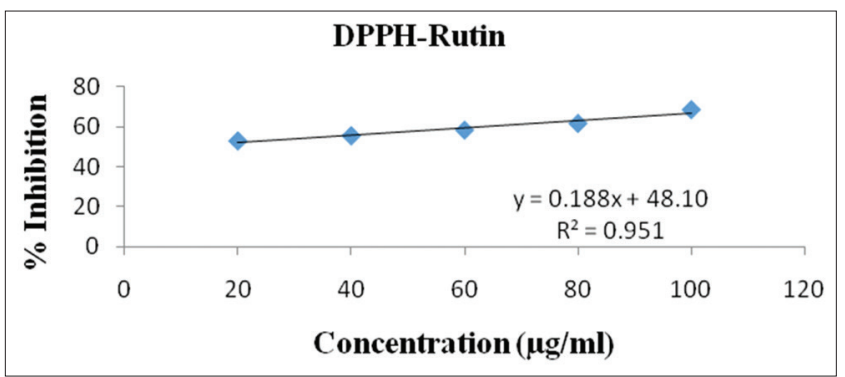

Fig. 1: 2,2-diphenyl-1-picrylhydrazyl (DPPH) radical scavenging assay whereas \% DPPH inhibition is plotted against concentrations of rutin taken as standard

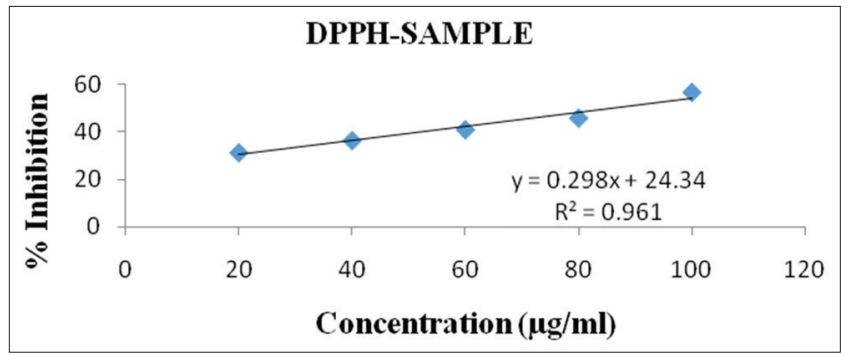

Fig. 2: 2,2-diphenyl-1-picrylhydrazyl (DPPH) radical scavenging assay whereas \% DPPH inhibition is plotted against concentrations of aqueous root extract 
Table 2: Superoxide scavenging assay

\begin{tabular}{lllllll}
\hline S.No & $\begin{array}{l}\text { Concentration } \\
(\boldsymbol{\mu g} / \mathbf{m l})\end{array}$ & \multicolumn{2}{l}{ Inhibition $(\%)$} & & \multicolumn{2}{l}{ IC $_{\mathbf{5 0}}(\boldsymbol{\mu g} / \mathbf{m l})$} \\
\cline { 3 - 4 } & & Rutin & Sample & & Rutin & Sample \\
\hline 1 & 20 & $51.95 \pm 0.026$ & $25.61 \pm 0.377$ & & 11.18 & 107.59 \\
2 & 40 & $57.30 \pm 0.226$ & $34.05 \pm 0.038$ & & \\
3 & 60 & $66.77 \pm 0.234$ & $38.06 \pm 0.029$ & & \\
4 & 80 & $72.42 \pm 0.261$ & $42.28 \pm 0.290$ & & \\
5 & 100 & $74.07 \pm 0.062$ & $47.73 \pm 0.186$ & & \\
\hline$I_{50}:$ Inhibitory concentration $50 \%$ & & & &
\end{tabular}

Table 3: FRAP assay

\begin{tabular}{llll}
\hline S.No & $\begin{array}{l}\text { Concentration } \\
(\mu \mathrm{g} / \mathrm{ml})\end{array}$ & Absorbance & \\
\cline { 3 - 4 } & & Rutin & Sample \\
\hline 1 & 20 & $0.134 \pm 0.007$ & $0.094 \pm 0.005$ \\
2 & 40 & $0.162 \pm 0.023$ & $0.127 \pm 0.009$ \\
3 & 60 & $0.189 \pm 0.006$ & $0.149 \pm 0.008$ \\
4 & 80 & $0.216 \pm 0.005$ & $0.181 \pm 0.011$ \\
5 & 100 & $0.244 \pm 0.020$ & $0.197 \pm 0.013$ \\
\hline
\end{tabular}

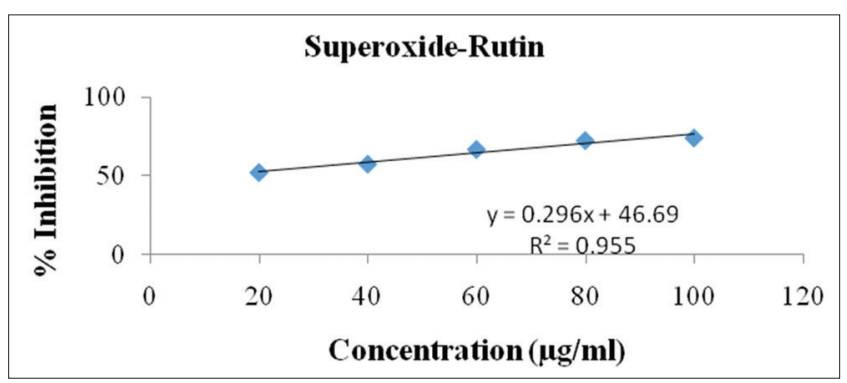

Fig. 3: Superoxide scavenging assay whereas \% superoxide scavenging inhibition is plotted against concentrations of rutin

\section{CONCLUSIONS}

From the current study, we can conclude that $C$. serratum aqueous extract has significant antioxidant activity against DPPH scavenging assay, superoxide scavenging assay, and FRAP assay. This radical scavenging activity could be attributed to the presence of flavonoids, alkaloids, glycosides, and phenolic compounds. Plant exhibits the antioxidant activity through the scavenging of free radicals, and FRAP showed significant reducing power activity with increased concentration of the sample. The results suggest that the traditional value of the plant could be attributed to its antioxidant potential.

\section{REFERENCES}

1. Mohammad Y, Mohammad I. Antiasthmatic herbal drugs: A review. Int J Pharm Pharm Sci 2010;2:28-9.

2. Sumanta KG, Nonigopal G, Avijit S, Anupam G. Traditional herbal remedies for various ailments within the rural communities in the district of Bankura and Purulia, West Bengal, India. Int J Pharm Pharm Sci 2013;5:195-8.

3. Aravind G, Bhowmik D, Duraivel S, Harish G. Traditional and medicinal uses of Carica papaya. J Med Plants Stud 2013;1(1):7-15.

4. Ghosh T, Maity KT, Sengupta P, Dash KD, Bose A. Antidiabetic and in-vivo antioxidant activity of ethanolic extract of Bacopa monnieri L. Aerial parts: A possible mechanism of action. Iran J Pharm Res 2008;7(1):61-8

5. Han X, Shen T, Lou H. Dietary polyphenols and their biological

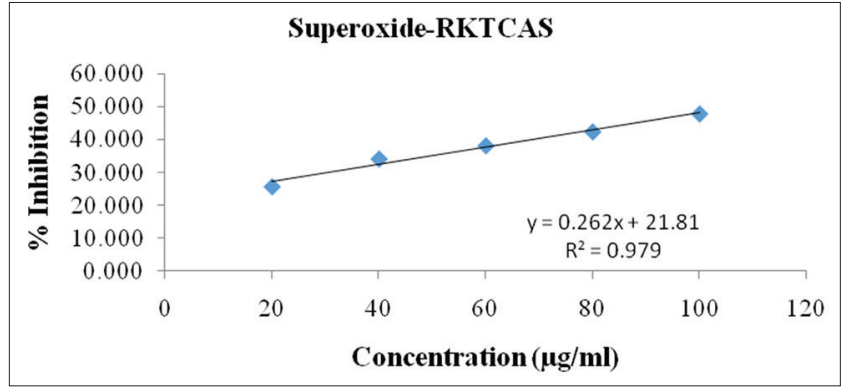

Fig. 4: Superoxide scavenging assay whereas \% superoxide scavenging inhibition is plotted against concentrations of aqueous root extract

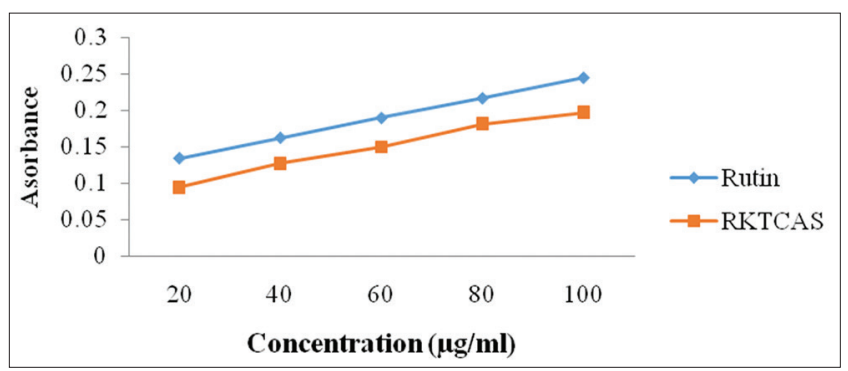

Fig. 5: Ferric reducing antioxidant power assay showing antioxidant capacity based on the ability to reduce ferric ions of sample with increase in absorbance of sample and standard

significance. Int J Mol Sci 2007;8(9):950-88.

6. Brieger K, Schiavone S, Miller FJ, Krause KH. Reactive oxygen species: From health to disease. Swiss Med Wkly 2012;142:13659.

7. Frei B. Cardiovascular disease and nutrient antioxidants: Role of low-density lipoprotein oxidation. Crit Rev Food Sci Nutr 1995;35(1-2):83-98.

8. Devasagayam TP, Tilak JC, Boloor KK, Sane KS, Ghaskadbi SS, Lele RD. Free radicals and antioxidants in human health: Current status and future prospects. J Assoc Physicians India 2004;52:794-804.

9. Suzuki T, Wakai K, Matsuo K, Hirose K, Ito H, Kuriki K, et al. Effect of dietary antioxidants and risk of oral, pharyngeal and laryngeal squamous cell carcinoma according to smoking and drinking habits. Cancer Sci 2006;97:760-7.

10. Ismail A Jr, Tan S. Antioxidant activity of selected commercial seaweeds. Malays J Nutr 2002;8(2):167-77.

11. Manjunatha BK, Krishna V, Pillaiah T. Flora of Davanagere District, Karnataka, India. New Delhi: Regency Pulications; 2004.

12. Keshavamurthy KR. Medicinal Plants of Karnataka. Bangalore: Karnataka Forest Department; 1994.

13. Ramya P, Lakshmidevi N. Studies on anti-oxidant activity of Tinospora cardifolia (Miers). J Am Sci 2010;6(10):736-43.

14. Neha P, Dushyant B. Antioxidant activity of ethanolic extract of Annona squamosa Linn bark. Int $\mathrm{J}$ Res Pharm Biomed Sci 2011;2:1692-7.

15. Veerapur VP, Prabhakar KR, Parihar VK, Kandadi MR, Ramakrishana S, Mishra B, et al. Ficus racemosa stem bark extract: A potent antioxidant and a probable natural radioprotector. Evid Based Complement Alternat Med 2009;6(3):317-24.

16. Benzie IF, Strain JJ. The ferric reducing ability of plasma (FRAP) as a measure of "antioxidant power": The FRAP assay. Anal Biochem 1996;239(1):70-6

17. Nishaa S, Vishnupriya M, Sasikumar JM, Christabel HP, Gopalakrishnan VK. Antioxidant activity of ethanolic extract of Maranta arundinacea. L tuberous rhizomes. Asian J Pharm Clin Res 2012;5(4):85-8. 